\title{
ROLE OF TRIPLE VESSEL DOPPLER ULTRASONOGRAPHY IN PREDICTION OF PERINATAL OUTCOME IN HIGH RISK PREGNANCY
}

\section{Obstetrics \& Gynecology}

\begin{tabular}{ll} 
Manasa R* & Senior Resident, Department of OBG, BMCRI, Bengaluru. *Corresponding Author \\
\hline Priyanka & $\begin{array}{l}\text { Assistant Professor, Department of OBG, Gulbarga Institute of Medical Sciences, } \\
\text { Kalaburgi. }\end{array}$
\end{tabular}

\section{ABSTRACT}

BACKGROUND AND OBJECTIVES: To evaluate the role of Doppler ultrasonography in predicting the perinatal outcome in high-risk pregnancy and to establish its role in management of high-risk pregnancy. MATERIALS AND METHODS: The present study is a prospective study of Doppler ultrasound evaluation of uterine artery, umbilical artery and middle cerebral artery in 100 high-risk pregnant women, performed between 28 and 34 weeks of gestation. Doppler index Pulsatility index (PI) for each above mentioned artery and cerebro-placental ratio (CPR) will be calculated. Doppler Pulsatility index for the corresponding gestational age were compared with the reference values. The results of the Doppler ultrasound and AFI will be used for analysis of mode of delivery and perinatal outcome in the form of birth weight, APGAR score, NICU admission, perinatal mortality. RESULTS: Among newborns 46(46\%) were admitted to NICU, 64(64\%) of neonates had birth weight less than $2.5 \mathrm{~kg}$, there were 17 perinatal deaths. Of the 17 perinatal deaths, 2 cases had reverse end diastolic Flow (REDF) and 12 had absent end diastolic Flow (AEDF). Uterine artery PI was most sensitive (72.3\%) than Umbilical artery PI(sensitivity 59.6\%) and MCA PI(sensitivity $68.1 \%$ ).

Diagnostic accuracy of Cerebroplacental ratio (accuracy $71 \%$ ) was better than Umbilical artery PI (accuracy 65\%) and MCA PI(accuracy 70\%) in predicting adverse outcomes. CONCLUSION: Triple vessel colour Doppler sonography is very useful in high-risk pregnancy diagnosis and in predicting perinatal outcome.

\section{KEYWORDS}

High-risk Pregnancy, Triple Vessel Colour Doppler, Pulsatility Index (PI), Cerebro-placental Ratio (CPR), Perinatal Outcome.

\section{INTRODUCTION:}

High risk pregnancy requires sophisticated maternal and fetal surveillance to help in its management decisions so as to ensure an optimal outcome for both mother and her newborn. A pregnancy at risk needs to be identified at an earlier state, in order to have an effective intervention strategy to deal with its complications. The two major conditions associated with placental dysfunction: Pre-eclampsia and IUGR(Intrauterine Growth Restriction)

Hypertensive disorders remains among the most significant unsolved problems in obstetrics. This complicates 5 to 10 percent of all pregnancies, and together they are one of the deadly triad-along with hemorrhage and infection-that contributes greatly to maternal morbidity and mortality rates. Defects in endovascular trophoblastic invasion with pre-eclampsia syndrome results in compromised uteroplacental perfusion is a major culprit in greater perinatal morbidity and mortality.

IUGR is defined as fetal growth less than the normal growth potential of a specific infant because of genetic, environmental, maternal and placental factors. World over, IUGR is observed in about $24 \%$ of newborns. In Asia it accounts for nearly $75 \%$ of affected infants. In India, incidence of IUGR reported to be $9.65 \%$ among hospital born live birth infants.

Doppler ultrasound is a rapid non-invasive test that provides valuable information about hemodynamic situation of the fetus and is an efficient diagnostic test of fetal jeopardy that helps in management of high-risk pregnancy. Doppler ultrasound evaluates uteroplacental and fetoplacental circulation

Uterine artery Doppler has been used to estimate resistance in uteroplacental blood flow.

Umbilical artery Doppler indicates extreme downstream resistance, placental dysfunction and fetal compromise.

Middle cerebral artery Doppler evaluates altered cerebral circulation before there is hypoxemia significant enough to alter the fetal heart rate patter. $^{3}$

Our study was an effort at establishing the role of Uterine artery(UtA), Umbilical artery(UA) and Middle Cerebral Artery(MCA) Doppler ultrasonography in prediction of perinatal outcome in high-risk pregnancy and to determine the role Doppler in management of highrisk pregnancy.

\section{METHODOLOGY}

\section{MATERIALS AND METHODS}

Source of data:

data for the study was collected from all women with high risk pregnancy attending department of Obstetrics and Gynaecology in Chigateri hospital, Women and Children hospital and Bapuji hospital, attached to J.J.M medical college, Davangere

Duration of study:

two years from November 2016 to September 2018

Inclusion criteria :

1. Singleton pregnancy with gestational age between 28 and 34 weeks.

2. Women with reliable dating of pregnancy confirmed by an early first trimester ultrasound examination using CRL or BPD or with known LMP will be selected.

3. High-risk pregnancy Pre-eclampsia, IUGR, BOH

Exclusion criteria:

1. Rupture of membranes,

2. Multiple pregnancies

3. Fetuses with congenital anomalies,

4. Intrauterine Fetal Demise.

\section{Sample size: 100}

\section{STATISTICALANALYSIS}

The data was compiled in Microsoft (MS) Excel work sheet and analysed using SPSS (Statistical Package for Social Sciences) software version 23 .

Statistical analysis was done by using proportion. The sensitivity, specificity, positive predictive value, negative predictive value and diagnostic accuracy were determined for all Doppler measurements.

\section{RESULTS}

TABLE 1: Age distribution of study cases

\begin{tabular}{|l|l|l|}
\hline Age (years) & No.of patients & Percentage \% \\
\hline $18-25$ & 62 & 62.0 \\
\hline $26-30$ & 30 & 30.0 \\
\hline $31-35$ & 6 & 6.0 \\
\hline$>35$ & 2 & 2.0 \\
\hline Total & 100 & 100 \\
\hline
\end{tabular}

$62 \%$ of patients were between $18-25$ age group 
TABLE 2: Gravidity distribution of study cases

\begin{tabular}{|l|l|l|}
\hline Gravida & No. of patients & Percentage \\
\hline Primi & 60 & 60.0 \\
\hline Multi & 40 & 40.0 \\
\hline
\end{tabular}

$60 \%$ of patients were primigravida

TABLE 3: Amniotic fluid distribution in study cases

\begin{tabular}{|c|c|c|c|c|}
\hline \multirow{2}{*}{ AFI } & \multicolumn{2}{|c|}{ Doppler } & \multirow{2}{*}{ Total } & \multirow{2}{*}{ P value } \\
\cline { 2 - 4 } & Abnormal & Normal & & \\
\hline \multirow{2}{*}{ Normal } & 2 & 36 & 38 & \multirow{2}{*}{0.000} \\
\cline { 2 - 4 } & $5.3 \%$ & $94.7 \%$ & $100.0 \%$ & \multirow{2}{*}{} \\
\hline \multirow{2}{*}{ Oligo } & 32 & 30 & 62 & \\
\cline { 2 - 4 } & $51.6 \%$ & $48.4 \%$ & $100.0 \%$ & \multicolumn{1}{|}{} \\
\hline \multirow{2}{*}{ Total } & 34 & 66 & 100 & \\
\cline { 2 - 4 } & $34.0 \%$ & $66.0 \%$ & $100.0 \%$ & \\
\hline
\end{tabular}

Among 34 patients with abnormal Doppler, 32(94.1\%) patients had oligohydramnious.

TABLE 4: Distribution characteristics of placental maturity

\begin{tabular}{|c|c|}
\hline Placental grading & No. of patients(\%) \\
\hline 2 & $48(48.0 \%)$ \\
\hline 3 & $52(52.0 \%)$ \\
\hline Total & $100(100.0 \%)$ \\
\hline
\end{tabular}

52 patients had grade 3 placenta and 48 patients had grade 2 placenta Association of Doppler Indices with Mode of delivery

TABLE 5: Doppler velocimetry and Mode of delivery

\begin{tabular}{|c|c|c|c|c|c|}
\hline \multicolumn{2}{|c|}{ Doppler indices } & $\begin{array}{l}\text { Vaginal } \\
\text { delivery } \\
\text { n (\%) }\end{array}$ & $\begin{array}{l}\text { Cesarean } \\
\text { delivery } \\
\text { n (\%) }\end{array}$ & $\begin{array}{l}\text { Chi- } \\
\text { square } \\
\text { P-value }\end{array}$ & O.R \\
\hline \multirow{2}{*}{$\begin{array}{l}\text { Umblical } \\
\text { artery } \\
\text { Doppler P }\end{array}$} & Normal & $38(67.9 \%)$ & $18(32.1 \%)$ & \multirow[t]{2}{*}{$\begin{array}{l}9.84 \\
\mathrm{P}<0.002\end{array}$} & $\begin{array}{l}1 \text { (ref. } \\
\text { category) }\end{array}$ \\
\hline & Abnormal & $16(36.4 \%)$ & $28(63.6 \%)$ & & $\begin{array}{l}3.694 \\
(1.61-8.49)\end{array}$ \\
\hline \multirow[t]{2}{*}{$\begin{array}{l}\text { Uterine } \\
\text { artery PI }\end{array}$} & Normal & $28(63.6 \%)$ & $16(36.4 \%)$ & \multirow[t]{2}{*}{$\begin{array}{l}2.937 \\
\mathrm{P}=0.087\end{array}$} & $\begin{array}{l}1 \text { (ref. } \\
\text { category) }\end{array}$ \\
\hline & Abnormal & $26(46.4 \%)$ & $30(53.6 \%)$ & & $\begin{array}{l}2.019 \\
(0.9-4.53)\end{array}$ \\
\hline \multirow[t]{2}{*}{ MCA PI } & Normal & $34(64.2 \%)$ & $19(35.8 \%)$ & \multirow[t]{2}{*}{$\begin{array}{l}4.678, \\
P=0.031\end{array}$} & $\begin{array}{l}1 \text { (ref. } \\
\text { category) }\end{array}$ \\
\hline & Abnormal & $20(42.6 \%)$ & $27(57.4 \%)$ & & $\begin{array}{l}2.416 \\
(1.08-5.41)\end{array}$ \\
\hline \multirow[t]{2}{*}{ CPR } & Normal & $40(64.5 \%)$ & $22(35.5 \%)$ & \multirow[t]{2}{*}{$\begin{array}{l}7.26 \\
\mathrm{P}<0.007\end{array}$} & $\begin{array}{l}1 \text { (ref. } \\
\text { category) }\end{array}$ \\
\hline & Abnormal & $14(36.2 \%)$ & $24(63.2 \%)$ & & $\begin{array}{l}3.12 \\
(1.35-7.22)\end{array}$ \\
\hline
\end{tabular}

The cesarean delivery rate was high at $46 \%$ as this was a high-risk group and threshold for cesarean was low. As study included gestation age between 28-34 weeks and needed delivery for various obstetric and maternal indications, cesarean was restored to owing to the fact response to induction is poor in early preterm patients with unfavourable cervix. Prolonged induction and delivery would not be in the interest of compromised fetuses.

Caesarean delivery is more common in abnormal umbilical artery PI, MCAPI and CPR but no so with abnormal uterine artery PI.

TABLE 6: Mode of delivery

\begin{tabular}{|l|l|}
\hline Mode of delivery & No. of cases(Percentage) \\
\hline Preterm vaginal delivery & $40(40.0 \%)$ \\
\hline Preterm LSCS & $34(34.0 \%)$ \\
\hline Term vaginal delivery & $18(18.0 \%)$ \\
\hline Term LSCS & $8(8.0 \%)$ \\
\hline TOTAL & $100(100.0 \%)$ \\
\hline
\end{tabular}

$74 \%$ had preterm delivery and $36 \%$ had term delivery.

\section{Association of Doppler Indices with NICU Admission}

TABLE 7: Doppler velocimetry and NICU Admission

\begin{tabular}{|l|l|l|l|l|}
\hline Doppler indices & $\begin{array}{l}\text { Absent } \\
\text { n (\%) }\end{array}$ & $\begin{array}{l}\text { Present } \\
\text { n (\%) }\end{array}$ & $\begin{array}{l}\text { Chi-square } \\
\text { P- value }\end{array}$ & O.R \\
\hline
\end{tabular}

20 International Journal of Scientific Research

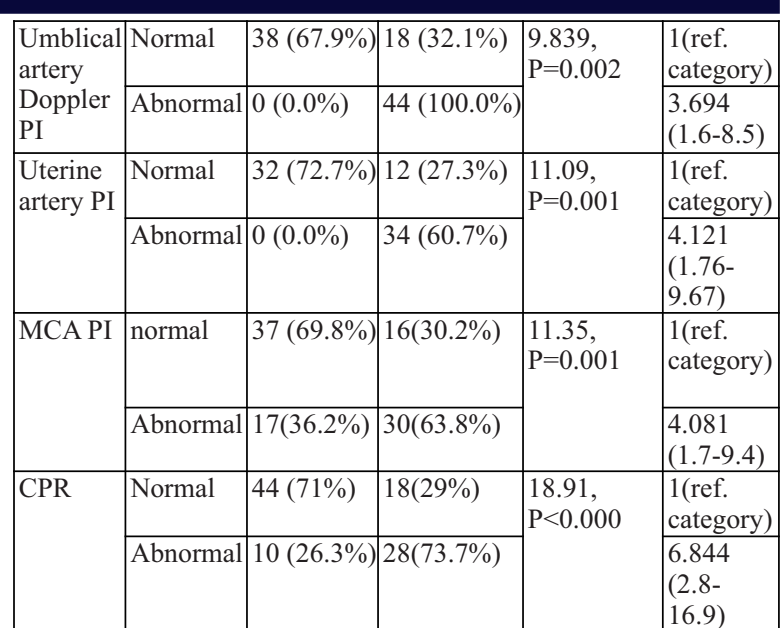

CPR is significantly associated with NICU admission $\left(\chi^{2}=18.9, \mathrm{p}<\right.$ $0.000)$. Women who had lower CPR had 6.844 times higher risk of NICU admission of their baby.

\section{Association of Doppler Indices with APGAR score}

TABLE 8: Doppler velocimetry and APGAR Score

\begin{tabular}{|c|c|c|c|c|c|}
\hline \multicolumn{2}{|c|}{ Doppler indices } & \multirow{2}{*}{\begin{tabular}{|l|}
$\begin{array}{l}\text { Normal } \\
\text { APGAR } \\
\text { n (\%) }\end{array}$ \\
$42(75 \%)$
\end{tabular}} & \multirow{2}{*}{\begin{tabular}{|l|l|}
$\begin{array}{l}\text { Low } \\
\text { APGAR } \\
\text { n (\%) }\end{array}$ \\
$14(25 \%)$
\end{tabular}} & \multirow{2}{*}{$\begin{array}{l}\begin{array}{l}\text { Chi- } \\
\text { square } \\
\text { P-value }\end{array} \\
15.1, \\
\mathrm{P}<0.000\end{array}$} & \multirow{2}{*}{\begin{tabular}{|l} 
O.R \\
$\begin{array}{l}\text { 1(ref. } \\
\text { category) }\end{array}$
\end{tabular}} \\
\hline $\begin{array}{l}\text { Umblical } \\
\text { artery }\end{array}$ & Normal & & & & \\
\hline $\begin{array}{l}\text { Doppler } \\
\text { PI }\end{array}$ & High & $16(36.4 \%)$ & $28(63.6 \%)$ & & $\begin{array}{l}5.25 \\
(2.22-12.4)\end{array}$ \\
\hline \multirow[t]{2}{*}{$\begin{array}{l}\text { Uterine } \\
\text { artery PI }\end{array}$} & Normal & $30(72.7 \%)$ & $12(27.3 \%)$ & \multirow{2}{*}{$\begin{array}{l}6.99 \\
\mathrm{P}=0.008\end{array}$} & $\begin{array}{l}\text { 1(ref. } \\
\text { category) }\end{array}$ \\
\hline & Abnormal & $26(46.4 \%)$ & $30(53.6 \%)$ & & $\begin{array}{l}3.07 \\
(1.3-7.17)\end{array}$ \\
\hline \multirow[t]{2}{*}{ MCA PI } & Normal & $41(77.4 \%)$ & $12(22.6 \%)$ & \multirow{2}{*}{$\begin{array}{l}17.35 \\
\mathrm{P}<0.000\end{array}$} & $\begin{array}{l}\text { 1(ref. } \\
\text { category) }\end{array}$ \\
\hline & Abnormal & $17(36.2 \%)$ & $30(63.8 \%)$ & & $\begin{array}{l}6.03 \\
(2.5-14.5)\end{array}$ \\
\hline \multirow[t]{2}{*}{ CPR } & Normal & $48(77.4 \%)$ & $14(22.6 \%)$ & \multirow[t]{2}{*}{$\begin{array}{l}25.26 \\
\mathrm{P}<0.000\end{array}$} & $\begin{array}{l}1 \text { (ref. } \\
\text { category) }\end{array}$ \\
\hline & Abnormal & \begin{tabular}{|l|}
$10(26.3 \%)$ \\
\end{tabular} & $28(73.7 \%)$ & & $\begin{array}{l}9.6 \\
(3.76-24.5)\end{array}$ \\
\hline
\end{tabular}

CPR is significantly associated with low APGAR $\operatorname{score}\left(\chi^{2}=25.26\right.$, $\mathrm{p}<0.000)$.

Women who had abnormal CPR are 9.6 times increased risk of having baby with Low APGAR score.

\section{Association of Doppler indices with Perinatal mortality}

TABLE 9: Doppler velocimetry and perinatal mortality

\begin{tabular}{|c|c|c|c|c|c|}
\hline \multicolumn{2}{|c|}{ Doppler indices } & $\begin{array}{l}\text { absent } \\
\text { n }(\%)\end{array}$ & $\begin{array}{l}\text { present } \\
\text { n }(\%)\end{array}$ & $\begin{array}{l}\text { Chi- } \\
\text { square } \\
\text { P- value }\end{array}$ & O.R \\
\hline \multirow{2}{*}{$\begin{array}{l}\text { Umblical } \\
\text { artery } \\
\text { Doppler } \\
\text { PI }\end{array}$} & Normal & $53(94.6 \%)$ & $3(5.4 \%)$ & \multirow{2}{*}{$\begin{array}{l}12.23 \\
\mathrm{P}<0.000\end{array}$} & $\begin{array}{l}\text { 1(ref. } \\
\text { category) }\end{array}$ \\
\hline & Abnormal & $30(68.2 \%)$ & $14(31.8 \%)$ & & $\begin{array}{l}8.2 \\
(2.2-31.02)\end{array}$ \\
\hline \multirow[t]{2}{*}{$\begin{array}{l}\text { Uterine } \\
\text { artery PI }\end{array}$} & Normal & $43(97.7 \%)$ & $1(2.3 \%)$ & \multirow{2}{*}{$\begin{array}{l}12.08 \\
\mathrm{P}=0.001\end{array}$} & $\begin{array}{l}\text { 1(ref. } \\
\text { category) }\end{array}$ \\
\hline & Abnormal & $40(71.4 \%)$ & $16(28.6 \%)$ & & $\begin{array}{l}17.2 \\
(2.2-135.7)\end{array}$ \\
\hline \multirow[t]{2}{*}{ MCA PI } & Normal & $52(98.1 \%)$ & $1(1.9 \%)$ & \multirow[t]{2}{*}{$\begin{array}{l}18.25 \\
\mathrm{P}<0.000\end{array}$} & $\begin{array}{l}\text { 1(ref. } \\
\text { category) }\end{array}$ \\
\hline & Abnormal & $31(66.6 \%)$ & $16(34 \%)$ & & $\begin{array}{l}26.839 \\
(3.4-212.4)\end{array}$ \\
\hline \multirow[t]{2}{*}{ CPR } & Normal & $59(95.2 \%)$ & $3(4.8 \%)$ & \multirow{2}{*}{$\begin{array}{l}17.1 \\
\mathrm{P}<0.000\end{array}$} & $\begin{array}{l}\text { 1(ref. } \\
\text { category) }\end{array}$ \\
\hline & Abnormal & $24(63.2 \%)$ & $14(36.8 \%)$ & & $\begin{array}{l}11.5 \\
(3.02-43.6)\end{array}$ \\
\hline
\end{tabular}


MCA PI is significantly associated with perinatal mortality $\left(\chi^{2}=18.25\right.$, $\mathrm{p}<0.000$ ). Women with abnormal MCA PI is 11.5 times increased risk with perinatal mortality.

\section{Association of Doppler Indices with overall Perinatal outcome}

TABLE 10: Doppler velocimetry and overall Perinatal outcome

\begin{tabular}{|l|l|l|l|l|l|}
\hline Doppler indices & $\begin{array}{l}\text { Uneventful } \\
\text { n (\%) }\end{array}$ & $\begin{array}{l}\text { Eventful } \\
\text { n (\%) }\end{array}$ & $\begin{array}{l}\text { Chi- } \\
\text { square } \\
\text { P-value }\end{array}$ & O.R \\
\hline $\begin{array}{l}\text { Umblical } \\
\text { artery } \\
\text { Doppler PI }\end{array}$ & Normal & $37(66.1 \%)$ & $\begin{array}{l}19 \\
(33.9 \%)\end{array}$ & $\begin{array}{l}8.73, \\
\mathrm{P}=0.003\end{array}$ & $\begin{array}{l}1(\text { ref. } \\
\text { category })\end{array}$ \\
\cline { 2 - 6 } & Abnormal & $16(36.4 \%)$ & $\begin{array}{l}28 \\
(63.6 \%)\end{array}$ & & $\begin{array}{l}3.407 \\
(1.49-7.71)\end{array}$ \\
\hline $\begin{array}{l}\text { Uterine } \\
\text { artery PI }\end{array}$ & Normal & $31(70.5 \%)$ & $13(29.5 \%)$ & $\begin{array}{l}9.6, \\
\mathrm{P}=0.002\end{array}$ & $\begin{array}{l}1(\text { ref. } \\
\text { category })\end{array}$ \\
\cline { 2 - 6 } & Abnormal & $22(39.3 \%)$ & $\begin{array}{l}34 \\
(60.7 \%)\end{array}$ & $\begin{array}{l}3.685 \\
(1.59-8.54)\end{array}$ \\
\hline MCA PI & High & $38(71.7 \%)$ & $\begin{array}{l}15 \\
(28.3 \%)\end{array}$ & $\begin{array}{l}15.83, \\
\mathrm{P}<0.000\end{array}$ & $\begin{array}{l}1(\text { ref. } \\
\text { category })\end{array}$ \\
\cline { 2 - 6 } & Low & $15(31.9 \%)$ & $\begin{array}{l}32 \\
(68.1 \%)\end{array}$ & $\begin{array}{l}5.404 \\
(2.3-12.8)\end{array}$ \\
\hline CPR & Normal & $43(69.4 \%)$ & $\begin{array}{l}19 \\
(30.6 \%)\end{array}$ & $\begin{array}{l}17.52, \\
\mathrm{P}<0.000\end{array}$ & $\begin{array}{l}1(\text { ref. } \\
\text { category })\end{array}$ \\
\cline { 2 - 6 } & Abnormal & $10(26.3 \%)$ & $\begin{array}{l}28 \\
(73.7 \%)\end{array}$ & & $\begin{array}{l}6.337 \\
(2.57- \\
16.27)\end{array}$ \\
\hline
\end{tabular}

CRP is significantly associated with adverse perinatal outcome $\left(\left(\chi^{2}\right.\right.$ $=17.52, \mathrm{p}<0.000)$. women with abnormal CPR is 17.52 times increased risk of adverse perinatal outcome like low APGAR score, NICU Admission and Perinatal mortality.

\section{Doppler to Delivery interval}

TABLE 11: Doppler velocimetry and the duration between doppler and delivery

\begin{tabular}{|l|l|l|}
\hline \multirow{2}{*}{ Doppler to Delivery Interval } & Doppler \\
\cline { 2 - 3 } & Normal n (\%) & Abnormal n (\%) \\
\hline$<24 \mathrm{hrs}$ & $1(3.57 \%)$ & $27(96.43 \%)$ \\
\hline 1 to 2 weeks & $0(0.0 \%)$ & $30(100.0 \%)$ \\
\hline 3 to 4 weeks & $2(33.3 \%)$ & $4(66.7 \%)$ \\
\hline 5 to 6 weeks & $28(100 \%)$ & $0(0.0 \%)$ \\
\hline 7 to 8 weeks & $8(100.0 \%)$ & $0(0.0 \%)$ \\
\hline
\end{tabular}

Patients with abnormal Doppler has less Doppler to delivery interval like majority delivered within 2 weeks of Doppler examination.

\section{Performance characteristics of Doppler Indices}

TABLE 12: Performance characteristics of Doppler Indices

\begin{tabular}{|l|l|l|l|l|l|l|}
\hline Outcome & Parameters & $\begin{array}{l}\text { Sensitivity } \\
(\%)\end{array}$ & $\begin{array}{l}\text { Specificity } \\
(\%)\end{array}$ & PPV & NPV & $\begin{array}{l}\text { Diagnostic } \\
\text { accuracy }\end{array}$ \\
\hline $\begin{array}{l}\text { Perinatal } \\
\text { mortality }\end{array}$ & U.A PI & 82.4 & 63.9 & 31.8 & 63.9 & 67 \\
\cline { 2 - 7 } & Ut. A PI & 94.1 & 51.8 & 28.6 & 97.7 & 59 \\
\cline { 2 - 7 } & $\begin{array}{l}\text { Diastolic } \\
\text { notch }\end{array}$ & 94.1 & 66.3 & 36.4 & 98.2 & 71 \\
\cline { 2 - 7 } & MCA.PI & 94.1 & 62.7 & 34 & 98.1 & 68 \\
\cline { 2 - 7 } & CPR & 82.4 & 71.1 & 36.8 & 95.2 & 73 \\
\hline \multirow{4}{*}{$\begin{array}{l}\text { Low } \\
\text { APGAR }\end{array}$} & U.A PI & 66.7 & 72.4 & 63.6 & 75 & 70 \\
\cline { 2 - 7 } & Ut. A PI & 71.4 & 55.2 & 53.6 & 72.7 & 62 \\
\cline { 2 - 7 } & $\begin{array}{l}\text { Diastolic } \\
\text { notch }\end{array}$ & 61.9 & 69 & 59.1 & 71.4 & 66 \\
\cline { 2 - 7 } & MCA.PI & 71.4 & 70.7 & 63.8 & 77.4 & 71 \\
\cline { 2 - 7 } & CPR & 66.7 & 82.8 & 73.7 & 77.4 & 76 \\
\hline \multirow{4}{*}{$\begin{array}{l}\text { NICU } \\
\text { admission }\end{array}$} & U.A PI & 60.9 & 70.4 & 63.6 & 67.9 & 66 \\
\cline { 2 - 7 } & Ut. A PI & 73.9 & 59.3 & 60.7 & 72.7 & 66 \\
\cline { 2 - 7 } & $\begin{array}{l}\text { Diastolic } \\
\text { notch }\end{array}$ & 65.2 & 74.1 & 68.2 & 71.4 & 70 \\
\cline { 2 - 7 } & MCA.PI & 65.2 & 68.5 & 63.8 & 69.8 & 67 \\
\cline { 2 - 6 } & CPR & 60.9 & 81.5 & 73.7 & 71 & 72 \\
\hline
\end{tabular}

\begin{tabular}{|l|l|l|l|l|l|l|}
\hline \multirow{2}{*}{$\begin{array}{l}\text { Total } \\
\text { eventful } \\
\text { Outcome }\end{array}$} & U.A PI & 59.6 & 69.8 & 63.6 & 66.1 & 65 \\
\cline { 2 - 7 } & Ut. A PI & 72.3 & 58.5 & 60.7 & 70.5 & 65 \\
\cline { 2 - 7 } & $\begin{array}{l}\text { Diastolic } \\
\text { notch }\end{array}$ & 63.8 & 73.6 & 68.2 & 69.6 & 69 \\
\cline { 2 - 7 } & MCA.PI & 68.1 & 71.7 & 68.1 & 71.7 & 70 \\
\cline { 2 - 7 } & CPR & 59.6 & 81.1 & 73.7 & 69.4 & 71 \\
\hline
\end{tabular}

Performance characteristics of Doppler indices

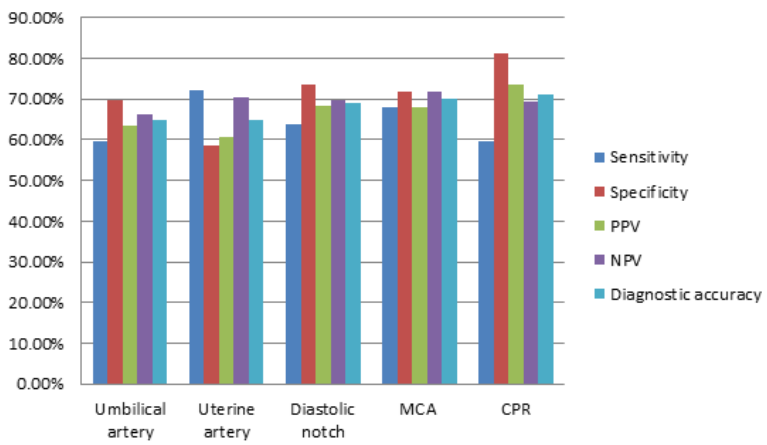

FIGURE 1: Graph showing Performance characteristics of Doppler Indices

Most sensitive was uterine artery $\mathrm{PI}(72.3 \%)$, most specific was CPR $(81.1 \%)$, high PPV was CPR(73.7\%), High NPV was MCA $\mathrm{PI}(71.7 \%)$ and most diagnostically accurate is $\mathrm{CPR}(71 \%)$.

\section{DISCUSSION}

High risk pregnancy are known to cause maternal and fetal morbidity and mortality. Adverse Fetal outcomes can be assessed by clinical examination as well as Doppler ultrasonography. Doppler velocimetry is a rapid non invasive test that provides information about hemodynamic status of the fetus at an early period of gestation when compared to clinical examination and is an efficient diagnostic test of fetal jeopardy that helps in management of high risk pregnancy. Doppler is been used to assess adverse perinatal outcome. ${ }^{5,6 .}$

In our study majority of the women were found below 25 years and primigravida similar to Gupta $\mathrm{P}$ et al. In our study majority of the women had PE and IUGR compared to B.O.H and majority of them had combination of both PE and IUGR similar to Gupta et.al ${ }^{8}$

Majority of the Indian studies conducted have only used 3 indices namely Um A PI, MCA PI and CPR.. ${ }^{9}$ Doppler velocimetry of the Uterine arteries reflects vascular impedance on the maternal side of the placental circulation. Increasing impedance, due to anomalous invasion of cytotrophoblastic cells into the decidual tissue of the placental bed, and defect remodelling of the spiral arteries, is reflected in decreasing diastolic blood flow velocities and/or persistent early diastolic notch in the uterine artery blood flow waveform. In pregnancies complicated by pre.eclampsia, increased uterine artery vascular impedance in the third trimester has been correlated with adverse perinatal outcomes such as small,for.gestational.age (SGA) newborns, delivery by caesarean section, premature delivery and admission to a neonatal intensive care unit (NICU). ${ }^{10,11}$

TABLE 13: Performance characteristics of umbilical artery PI in present study with reference range.

\begin{tabular}{|l|l|l|l|}
\hline & Fong K W et al & Gramellini et al & Present study \\
\hline Sensitivity & $44.7 \%$ & $64 \%$ & $59.6 \%$ \\
\hline Specificity & $86.6 \%$ & $90.7 \%$ & $69.8 \%$ \\
\hline PPV & $54 \%$ & $72.7 \%$ & $63.6 \%$ \\
\hline NPV & $81.7 \%$ & $86.7 \%$ & $66.1 \%$ \\
\hline
\end{tabular}

Umbilical artery was found to have low sensitivity of $59.6 \%$ when compared with uterine artery PI and MCA PI. This sensitivity was comparable with that of Fong KW et $\mathrm{al}^{48}$ and Gramellini et $\mathrm{al}^{49}$. The specificity of Umbilical artery PI $69.8 \%$ more than uterine artery PI but less compared to MCA PI and CPR. The PPV of Umbilical artery PI $63.6 \%$ more than uterine artery PI but less compared to MCA PI and CPR. The PPV of Umbilical artery PI is comparable with that of Fong KW et al and Gramellini et al. The NPV of Umbilical artery PI $66.1 \%$ less compared to any other variables.

Patients with absent end diastolic volume (AEDV) and reverse end 
diastolic volume (REDV) have the gravest outcome. Fetuses with AEDV require intensive surveillance as fetal wellbeing may deteriorate very fast. Fetuses with REDV are most severely

compromised. REDV indicate preterminal fetal state similar to Mishra D et al. ${ }^{1 .}$

Our findings confirms the result of Fong $\mathrm{K} \mathrm{W}$ et al, Gramellini et al that abnormal Umbilical artery PI is associated with adverse perinatal outcome like low APGAR score, NICU Admission and perinatal mortality. Our findings agree with Harrington et $\mathrm{al}^{15}$ that umbilical artery can be normal in term and late term with abnormal MCA.

TABLE 14: Perinatal outcomes in absent and reverse umbilical artery doppler in hypertensive groups.

\begin{tabular}{|l|l|l|}
\hline Spectral characteristic & No. of patients & Perinatal Mortality (\%) \\
\hline
\end{tabular}

\begin{tabular}{|l|l|l|}
\hline AEDF & 18 & $12(66.66 \%)$ \\
\hline REDF & 2 & $2(100 \%)$ \\
\hline
\end{tabular}

TABLE 15: Different studies showing high perinatal mortality in AEDF and REDF.

\begin{tabular}{|c|c|c|}
\hline Author & $\begin{array}{l}\text { Mortality in \% } \\
\text { (AEDF) }\end{array}$ & Mortality in \% (REDF) \\
\hline Bhatt et $\mathrm{al}^{16}$ & $50 \%$ & $50 \%$ \\
\hline Lakhar et $\mathrm{al}^{4}$ & $100 \%$ & $100 \%$ \\
\hline Smitha et $\mathrm{al}^{17}$ & $27.78 \%$ & $100 \%$ \\
\hline Srilakhshmi et al ${ }^{18}$ & $100 \%$ & $100 \%$ \\
\hline Present study & $66.66 \%$ & $100 \%$ \\
\hline
\end{tabular}

AEDF and REDF flow in the umbilical artery significantly influenced the risk of cerebral haemorrhage, anemia or hypoglycaemia. A caesarean section is recommended in all pregnancies complicated by $\mathrm{AEDF}$ and REDF if the gestational age and predicted neonatal weight can be handled by the NICU. ${ }^{19}$

TABLE 16: Performance characteristics of MCA PI in present study with reference range.

\begin{tabular}{|l|l|l|l|}
\hline & Fong K W et al & Gramellini et al & Present study \\
\hline Sensitivity & $72.4 \%$ & $24 \%$ & $68.1 \%$ \\
\hline Specificity & $58.1 \%$ & $100 \%$ & $71.7 \%$ \\
\hline PPV & $37.7 \%$ & $100 \%$ & $68.1 \%$ \\
\hline NPV & $85.7 \%$ & $77.3 \%$ & $71.7 \%$ \\
\hline
\end{tabular}

MCA was found to have sensitivity $68.1 \%$ more than umbilical artery PI, CPR and less than uterine artery PI. The values were compared with reference range as showed above.

It showed sensitivity of $68.1 \%$ similar to Fong $\mathrm{K} \mathrm{W}$ et al. Specificity of $71.7 \%$ almost similar to Fong $\mathrm{K} \mathrm{W}$ et al. study agrees with Fong K W et al that MCA PI is less specific than CPR. There are several possible explanation for plow specificity of the MCA PI for adverse perinatal outcome. Among several published normogram for MCAPI the cut off values for an abnormal MCA PI are similar up to about 30 weeks gestation age but differ after 32 weeks. The normograms we choose to use for analysis are from the largest published cross-sectional study by Harrington K et al.

MCA PI PPV $68.1 \%$ in predicting adverse perinatal outcome is also less than that of CPR, which can be attributed to the more false positive values.

The NPV of $71.7 \%$ is comparable to Fong $\mathrm{K} \mathrm{W}$ et al, more compared with umbilical artery PI, uterine artery PI and CPR. Thus indicating the usefulness of MCA PI in ruling out possibility of adverse perinatal outcome.

TABLE 17: Performance characteristics of CPR in present study with reference range.

\begin{tabular}{|l|l|l|l|}
\hline & Fong K W et al & Gramellini et al & Present study \\
\hline Sensitivity & $51.3 \%$ & $68 \%$ & $59.6 \%$ \\
\hline Specificity & $80.6 \%$ & $98.4 \%$ & $81.1 \%$ \\
\hline PPV & $48.1 \%$ & $94.4 \%$ & $73.7 \%$ \\
\hline NPV & $82.5 \%$ & $88.8 \%$ & $69.4 \%$ \\
\hline
\end{tabular}

CPR has highest specificity of $81.1 \%$ was found to be better than any other variable. The specificity was comparable with above mentioned studies. The CPR is effective to rule in the possibility of adverse perinatal outcome when it is abnormal
The PPV of CPR is $73.7 \%$ was more than that of other variables. It indicates the likelihood of adverse perinatal outcome in growth restricted fetus with abnormal CPR. The PPV of CPR was not much comparable to above mentioned studies.

The sensitivity of CPR $59.6 \%$ comparable with above mentioned studies. The NPV of CPR $69.4 \%$ was less than Uterine artery PI and MCAPI.

Our findings confirms the results of Fong $\mathrm{K} \mathrm{W}$ et al that abnormal CPR is associated with adverse perinatal outcome like Low APGAR score, NICU Admission and perinatal mortality.

\section{Uterine artery Doppler}

Sensitivity of uterine artery PI $72.3 \%$, more compared to any othe variable. Examination of both Uterine arteriesis an indispensable element of doppler examination to assess placental performance and risk to the fetus. ${ }^{20}$

Rai $\mathrm{L}$ et al suggested Uterine artery is a better predictor of Perinatal adverse outcome in third trimester, hence should be included in determination of adverse perinatal outcomes.

It showed specificity $58.5 \%$. the PPV $60.7 \%$ similar to Umbilical artery PI and NPV of $70.5 \%$ more than Umbilical artery PI.

Diastolic notch of uterine artery specificity $73.6 \%$,more compared to specificity of umbilical artery PI and MCA PI. This was different compared to Swapnali C. Kshirsagar et al observed that presence of notch has got maximum sensitivity and negative predictive value for adverse perinatal outcome.

Including uterine artery Doppler in the surveillance of growthrestricted fetuses might detect a group of pregnancies at high risk, even though the umbilical artery Doppler was normal.

In our study when we compare the overall diagnostic accuracy in prediction of adverse outcome in high-risk pregnancy, CPR has the diagnostic accuracy of $71 \%$ which is more than Umbilical artery $\mathrm{PI}(65 \%)$, uterine artery $\mathrm{PI}(65 \%)$ and $\mathrm{MCA} \mathrm{PI}(70 \%)$ similar to Gramellini et al.

TABLE 18: Diagnostic accuracy in Gramellini et al and present study

\begin{tabular}{|l|l|l|}
\hline & Gramellini et al & Present study \\
\hline CPR & $90 \%$ & $71 \%$ \\
\hline Umbilical artery PI & $83.3 \%$ & $65 \%$ \\
\hline MCA PI & $78.8 \%$ & $70 \%$ \\
\hline
\end{tabular}

MCAPI and CPR are strong predictors of adverse perinatal outcome.

Our study assesses four parameters of Doppler, multiple outcome of high risk pregnancy and was a Prospective study. The study was conducted both in private and government set up hence had population distribution from low as well as high economic status.

On assessing for association between adverse perinatal outcome we found that all the indices were significantly associated as demonstrated by previous studies. Ut A PI had higher sensitivity (72.3\%) compared to rest of the doppler indices but lower specificity (58.5\%). CPR had higher specificity $(81.1 \%)$. Diagnostic accuracy of CPR was higher $(87 \%)$ than other Doppler indices. Mishra D et.al and Singh M et.al claim that CPR is better indices than MCA PI and Um. A PI, as it measures both the indices together. Most of the studies show varied results and suggest all indices have to be considered together for prediction of perinatal outcome. Most of these studies didn't evaluate the importance of Uterine artery PI index. Earlier studies have shown that fetal redistribution may exist in the presence of normal umblical artey Doppler in late pregnancy. Hence fetal middle cerebral artery was included in evaluation of late gestational perinatal morbidity

\section{CONCLUSION}

Our study has succeeded in demonstrating the efficacy of Doppler in predicting the fetal outcome in high-risk pregnancy.

Doppler ultrasonography is the best noninvasive investigation to assess changes in fetal hemodynamics in pre-eclampsia and IUGR. 
- Doppler of multiple vessels will give more information, hence useful than single vessel changes.

- Doppler helps to differentiate the fetus with pathological growth restriction from that of other small for gestational age fetus.

- $\quad$ Raised uterine artery PI as in pre-eclampsia indicates reduced placental perfusion with maternal blood and consequent decrease in fetal arterial oxygen content.

- Raised umbilical artery PI- occurs when at least $60 \%$ of the placental vascular bed is obliterated and is the first pathological finding in growth restricted fetus.

- Absent and reversed end diastolic flow in umbilical artery is an ominous finding, associated with increased perinatal morbidity and mortality.

- Umbilical artery Doppler is an integral part of monitoting highrisk pregnancies.

- Adverse pregnancy outcome in third trimester is better predicted with uterine artery Doppler.

- Normal uterine artery Doppler in third trimester predicts good perinatal outcome and hence reassuring.

- Hence Doppler ultrasonography is essential for management of high-risk pregnancies.

\section{REFERENCES}

1. F. Gary Cunningham, Kenneth J. Leveno, Steven L. Bloom, Jodi S. Dashe, Barbara L. Hoffman, Brian M. Casey,, et al. Hypertensive disorders. In: Cunningham, F. Gary, editor. Williams obstetrics, 25th edition. New York: McGraw-Hill Education, 2018:710-54.

2. MurkiS, Sharma D Intrauterine Growth Retardation. JNeonatal Biol 2014:3:135.

3. Urmila S, Beena B. Triple vessel wave pattern by Doppler studies in normal and high risk pregnancies and perinatal outcome. Journal of Obstetrics and Gynecology of India 2010;60(4):312-316

4 Lakhar BN, Ahamed SA .Doppler Velocimetry of Uterine and Umbilical Arteries during Pregnancy.Ind J Radiol Imag 1999; 9: 3: 119-125.

5 Monika Singh, Archana Sharma, Parul Singh. Role of doppler indices in the prediction of adverse perinatal outcome in preeclampsia. National Journal of medical research 2013;3(4):315-18

6 Swapnali C. Kshirsagar, Sneha S. Shirodkar, Sunil J. Yadav, Umesh M. Zile Role of Doppler indices in prediction of perinatal outcome in preeclampsia Int J Reprod Doppler indices in prediction s. Shit

7 Jyoti Devi, Devender Kumar, Mala Shukla, P. K. Jain Doppler interrogation of fetoplacental circulation in hypertensive disorder of pregnancy and their perinatal outcomes. Int J Res Med Sci. 2017 Jun;5(6):2687-2693.

8 Gupta P, Mathur S, Khanna R. Doppler Triple-vessel wave pattern as a screening method for prediction of perinatal outcome in pregnancy-induced Hypertension. Journal South Asian Federation of Obstetrics and Gynecology.2017;9(2):173-78.

9 Zha C, Li J, Li X. Pulsatility indexes of fetal middle cerebral artery and umbilical artery for predicting intrauterine fetal growth retardation. Zhonghua Fu Chan $\mathrm{Ke} \mathrm{Za} \mathrm{Zhi}$ 1996Jun; 31(6):345-47.

10. Sieroszewski P, Guzowski G, Sosnowski D et al. The usefulness of uterine artery Doppler velocimetry in highrisk pregnancy diagnostic (PIH and/or IUGR). Ginekol Pol 2005;76:342-7.

11. Ghosh G, Gudmundsson S. Uterine and umbilical artery Doppler are comparable in predicting perinatal outcome of growth-restricted fetuses. BJOG 2009;116:424-430.

12. Fong KW, Ohlsson A, Hannah ME, Grisaru S, Kingdom J, Cohen H, Ryan M, Windrim R, Foster G, Amankwah K. Prediction of perinatal outcome in fetuses suspected to have IntraUterine Growth Restriction: Doppler US study of fetal cerebral, renal, and umbilical arteries. Radiology 1999;213(3):681-89.

13. Gramellini D, Folli MC, Raboni S, Vadora E, Merialdi A. Cerebral-umbilical Doppler ratio as a predictor of adverse perinatal outcome. Obstetrics and Gynecology 1992:79(3):416-20.

14. Mishra D et al., Role of Obstetric Doppler in Prediction of Adverse Perinatal Outcome in Intrauterine Growth Retardation and Pregnancy Induced Hypertension. Sch. J. App. Med. Sci., 2013; 1(6):1016-1020.

15. Harrington K, Carpenter RG, Nguyen M, Campbell S. changes observed in Doppler studies of the fetal circulation in pregnancies complicated by pre-eclampsia or the delivery of a small-for-gestational-age baby. I. Cross-sectional analysis Ultrasound Obstet Gynecol.1995;6(1):19-28.

16. Bhatt C J, Arora J, Shah M S. Role of color doppler in pregnancy induced hypertension (a study of 100 cases). Indian J Radiol Imag. 2003;13:417-20.

17. Smitha K, Sowmya K, Malathi T, Study of Doppler waveforms in pregnancy induced hypertension and its correlation with perinatal outcome Int J Reprod Contracept Obstet Gynecol. 2014;3(2):428-33.

18. Srilakshmi KN, Raghavendra, Khazi AA. study of triple vessel wave pattern by Doppler studies in low and high risk pregnancies and perinatal outcomes. J Evol Med Dent Sci. 2014;3(46):11160-5.

19. Karsdorp VH, van Vugt JM, van Geijn HP et al. Clinical significance of absent or reversed end diastolic velocity waveforms in umbilical artery. Lancet 1994:344:1664-8.

0. Hendrik J, Werner R. comparison of Doppler sonographic examinations of umbilical and uterine arteries in high risk pregnancies. Fetaldiagnther 1998;13:150-53 